\title{
Boosting the Affective Factors of Applied Linguistic UNDIP Students Using the Technique of Hypnosis
}

\author{
A Pre-experimental Research
}

\author{
Yusuf Al Arief, Fahmi Hidayat \\ Faculty of Teacher Training and Education \\ Universitas Lambung Mangkurat \\ Banjarmasin, Indonesia \\ yusufalarief@ulm.ac.id
}

\begin{abstract}
There are many factors affecting the success in teaching and learning process. One of them is the affective factor. Hypnosis as an alternative was applied in the teaching and learning process to help to overcome the problems from this factor. This study was aimed to analyze whether the hypnosis was effective or not in boosting the affective side of the students. This research was pre-experimental research with the one-group design. The data was collected by the interview method with a questionnaire as the instrument. From the analysis of the data, I found that the hypnosis gave significant effect toward the affective factors of the samples. It means that the hypnosis technique was effective to help to boost the affective factors of students in the teaching and learning process.
\end{abstract}

Keywords - affective, hypnosis, teaching and learning

\section{INTRODUCTION}

Teaching and learning process success has many factors behind it, whether from outside or from inside. Outside factors are like the material, media, facility, and techniques in teaching applied by teachers. Inside factors are like the motivation, the self-confidence, the courage to compete with others, and the intrinsic boost from the students' deepest heart. One of inside the factors influencing the success in teaching and learning is the affective domain [1]. The affective domain Affect is related to the emotion or the feeling of human being. When people have emotion and feeling toward teaching and learning, they will be more motivated in studying something. Brown classified four parts included in this affective domain. They are self-esteem, inhibition, risk-taking, and anxiety. Selfesteem is possibly the most common of any human behavior aspects. Simply, it is related to the term of self-confidence, the belief that you have the capability of doing something. Inhibition is simply the sets of defenses that grow naturally in the human being to protect the ego. Risk-Taking is an ability possessed by a human being. It is also known by "the ability to make intelligent guesses." [1] The next part of the affective domain is the anxiety. It is related to the feeling of uneasiness, frustration, self-doubt, apprehension, or worry. Some students often have difficulty in handling this affective factors. It needs special treatment to establish inner power related to studying any subjects.

Since there have not many researchers conducted research in this field, I was interested in applying a technique named hypnosis in order to boost the affective side of students. The objective of this research was to test the effectiveness of hypnosis in boosting the affective side of students, especially the students of Applied Linguistik of Magister Linguistik UNDIP students in batch 2013/2014

The technique called hypnosis is used basically by some psychologist to help the people who have a problem with their feeling domain. Hypnosis is a condition of increased suggestibility[2] [3]. They stated that the hypnotists, most of the time refer to two things: the conscious mind and the subconscious mind when they are working. The conscious mind refers to that you are aware of at this time being. It is your mind in the process of thinking, and since it has the being analytical and critical capability, it is able to neutralize most suggestions. Let's take an example if you don't really trust yourself that can succeed at school; you will find it hard to gain your score shows that you are categorized as successful. Then, when you truly believe that you have the ability to succeed, it is wonderful how you will simply be able to make yourself successful, in spite of the lots of challenges that you get at school. The other side, the subconscious mind, contains everything other than your present thoughts, and uniquely it has the unlimited capacity.

The hypnosis occurs when your conscious mind does not work for a while (i.e., when it stops being critical and judgmental)[2]. Once it is on a break, your subconscious mind automatically takes over it. When what is in your subconscious mind is positive, your achievement will be easier to achieve. This is because the subconscious tries to create whatever lies inside it. That doesn't say that Alderson stated that achieving important goals does not require any efforts. Instead, he explains that we have two parts of our mind working to achieve the same goal without internal conflict. Beginning as a discipline of therapeutic in the eighteenth century, hypnosis was the first conception of Western psychotherapy. When someone is under hypnosis, he is in the state of highly focused in attention added to the suspension of peripheral awareness. This great ability leads the person to link perception and cognition. This state is very useful. It can facilitate to reduce awareness of the unwanted stimuli, like pain, or of the problematic condition like depression or hopelessness. 
In the hypnosis world, the experts are also close to the term 'Metaphysical Generalizing.' [4]. It refers to the observing process to the actions and behavior of oneself and then assigning a judgment of value and label to that. When this process has been started by someone, and he starts to believe in it, it becomes what the experts call a self-fulfilling prophecy. Metaphysical generalizing has three basic and global categories:

- "I am fundamentally good (worthy)."

- "I am fundamentally no good (worthless)"

- "Sometimes I am good, and sometimes I am no good"

These three categories lead people to the external world, where:

- "Others are fundamentally good."

- "Others are fundamentally no good."

- Sometimes others are good, and sometimes others are no good."

In everything we do in our life, we as the owner of ourselves playing for the absolute value and worth of ourselves as human beings. This is the reason why people may hesitate, avoid, procrastinate, fall short and feel anxious. We, as human beings, are constantly torn between our existence of factual and our capacity of infinite to imagine and fantasize. Or simply, we are torn between our objective reality and subjective reality. But what we should remember, when we can label something it does not make us make the 'true' label on something. Relating to this, naturally human has a great power called the under-conscious world. If the labeling of everything is in this world, it has the ability to control our conscious world. This can be done by the hypnosis technique. As for the educational field, there are nine possible uses of hypnosis and suggestion. They are a) to reinforce positive habits and distinguish negative ones, b) to expand consciousness by increasing sensory and sensual response, c) to improve concentration, d) to aid memory, e) to increase motivation, f) to diminish "mental locks," g) to reduce anxiety, h) to encourage original thinking, and i) to develop selfconfidence

\section{METHOD}

Based on the problems raised in the form of lack of This paper was written as pre-experimental research and used onegroup design. In one-group design, the sample was given test called pre-test, given treatment, and then given the test again called post-test[5]. The design is as follows:

One-group pretest-posttest design

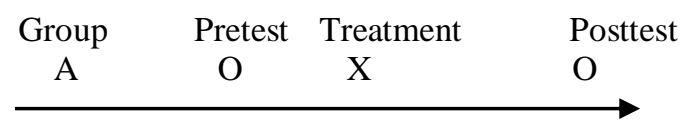

Time

The result of the pre-test and post-test were compared to see whether the treatment was effective or not. The test in this research was in the form of the questionnaire related to the affective factors measurement. The data is analyzed by using IBM SPSS Statistics 20. The population was the students of Applied Linguistics who were taking TEFL subject. From this population, we took 10 students as the sample.

\section{RESULT AND DISCUSSION}

In conducting the research, we firstly spread questionnaire to the students of Applied Linguistics to measure the affective level owned by the students. From the questionnaire, we collected the data of pre-test result. It is as follow:

TABLE I. PRETEST

\begin{tabular}{|l|c|c|c|c|c|c|c|c|l|}
\hline \multirow{2}{*}{ Initial } & \multicolumn{7}{|c|}{ Question } & \multirow{2}{*}{ Total } \\
\cline { 2 - 10 } & $\mathbf{1}$ & $\mathbf{2}$ & $\mathbf{3}$ & $\mathbf{4}$ & $\mathbf{5}$ & $\mathbf{6}$ & $\mathbf{7}$ & $\mathbf{8}$ & \\
\hline L1 & 4 & 4 & 3 & 5 & 5 & 5 & 5 & 5 & 36 \\
\hline MH & 5 & 5 & 3 & 5 & 5 & 5 & 4 & 5 & 37 \\
\hline P & 4 & 5 & 4 & 5 & 5 & 5 & 5 & 5 & 38 \\
\hline L2 & 4 & 4 & 3 & 4 & 4 & 3 & 5 & 5 & 32 \\
\hline Q & 4 & 5 & 3 & 3 & 5 & 3 & 5 & 5 & 33 \\
\hline AD & 5 & 5 & 4 & 4 & 5 & 4 & 5 & 5 & 37 \\
\hline A & 4 & 5 & 4 & 4 & 5 & 3 & 3 & 4 & 32 \\
\hline U & 4 & 5 & 2 & 3 & 1 & 2 & 5 & 5 & 27 \\
\hline ES & 4 & 4 & 3 & 4 & 5 & 3 & 5 & 4 & 32 \\
\hline AK & 5 & 4 & 4 & 5 & 5 & 4 & 4 & 5 & 36 \\
\hline
\end{tabular}

In order to see whether the instrument was valid or not, we used the SPSS program. The technique used was a half-split test where we used the odd score as variable 1 and even score as variable 2 . The odd and the even score are in the tables below:

TABLE II. THE ODD SCORE OF THE QUESTIONNAIRE

\begin{tabular}{|c|c|c|c|c|c|}
\hline \multirow{2}{*}{ Initial } & \multicolumn{4}{|c|}{ Odd } & \multirow{2}{*}{ Total } \\
\hline & 1 & 3 & 5 & 7 & \\
\hline L1 & 4 & 3 & 5 & 5 & 17 \\
\hline $\mathrm{MH}$ & 5 & 3 & 5 & 4 & 17 \\
\hline $\mathrm{P}$ & 4 & 4 & 5 & 5 & 18 \\
\hline L2 & 4 & 3 & 4 & 5 & 16 \\
\hline $\mathrm{Q}$ & 4 & 3 & 5 & 5 & 17 \\
\hline $\mathrm{AD}$ & 5 & 4 & 5 & 5 & 19 \\
\hline $\mathrm{A}$ & 4 & 4 & 5 & 3 & 16 \\
\hline $\mathrm{U}$ & 4 & 2 & 1 & 5 & 12 \\
\hline $\mathrm{ES}$ & 4 & 3 & 5 & 5 & 17 \\
\hline AK & 5 & 4 & 5 & 4 & 18 \\
\hline Total & & & & & 167 \\
\hline
\end{tabular}

TABLE III. THE EVEN SCORE OF THE QUESTIONNAIRE

\begin{tabular}{|c|c|c|c|c|c|}
\hline \multirow{2}{*}{ Initial } & \multicolumn{4}{|c|}{ Even } & \multirow{2}{*}{ Total } \\
\hline & 2 & 4 & 6 & 8 & \\
\hline L1 & 4 & 5 & 5 & 5 & 19 \\
\hline $\mathrm{MH}$ & 5 & 5 & 5 & 5 & 20 \\
\hline $\mathrm{P}$ & 5 & 5 & 5 & 5 & 20 \\
\hline L2 & 4 & 4 & 3 & 5 & 16 \\
\hline $\mathrm{Q}$ & 5 & 3 & 3 & 5 & 16 \\
\hline $\mathrm{AD}$ & 5 & 4 & 4 & 5 & 18 \\
\hline $\mathrm{A}$ & 5 & 4 & 3 & 4 & 16 \\
\hline $\mathrm{U}$ & 5 & 3 & 2 & 5 & 15 \\
\hline ES & 4 & 4 & 3 & 4 & 15 \\
\hline $\mathrm{AK}$ & 4 & 5 & 4 & 5 & 18 \\
\hline Total & & & & & 173 \\
\hline
\end{tabular}



below:

The result of the reliability test can be seen in Table 4

TABLE IV. INSTRUMENT RELIABILITY TEST

\begin{tabular}{|c|c|l|l|}
\hline \multirow{2}{*}{ odd } & $\begin{array}{c}\text { Pearson } \\
\text { Correlation }\end{array}$ & 1 & odd \\
\cline { 2 - 4 } & $\boldsymbol{N}$ & 10 & 0.571 \\
\hline \multirow{2}{*}{ even } & $\begin{array}{c}\text { Pearson } \\
\text { Correlation }\end{array}$ & 0.571 & 10 \\
\cline { 2 - 4 } & $\boldsymbol{N}$ & 10 & 1 \\
\hline
\end{tabular}

In order to see the figure out the whole reliability, we used the Spearman-Brown formula of coefficient correlation.

$$
\begin{aligned}
& r_{11}=2 \times r_{x y} / 1+r_{x y} \\
& r_{11}=2 \times 0.571 / 1+0.571 \\
& r_{11}=1.142 / 1.571 \\
& r_{11}=0.727
\end{aligned}
$$

Based on the calculation, we can see that the instrument has a high Level of reliability since the coefficient correlation is 0,727 .

Having found that the instrument was reliable, we decided to use it in collecting the data. After spreading the questionnaire as the measurement, we applied the treatment. The treatment itself was divided into some steps.

- First, we asked the participants whether or not they wanted to have the hypnosis process. Then, we asked the participants who agreed to have the hypnosis to choose a sitting location and position that made them feel comfortable.

- Next, I asked them to close their eyes and try to relax while listening to the instrumental music we intentionally played - the instrumental music is containing the sound of the flowing water, the rain, and the piano.

- After they felt relaxed, we asked them to imagine that they were in a place doing something.

- Then, we began to touch their emotion by asking them imagining about their parents who were always there for them and were sacrificing everything to make them successful.

- When their emotion had been influenced, we continued asking them to imagine every wrong thing that they had done to their parents. This put them in the weakest condition of mental and touched their deep feeling and emotion.

- Having done this, we continued the treatment by making them promise to themselves that no matter what the problems they may have or face in studying at UNDIP, they would always try to do their best to repay their mistakes to their parents.
- After asking them to promise, we asked them to relax and ensure them that the time they have in the future will be a great modal for them to be a better person in order to make their parents proud. The relaxation itself was still going along with listening to instrumental music.

- When they had felt relax, we asked them to open their eyes slowly.

- Finally, we asked them to manage their breath to help them be in the normal state.

After they gained the fully conscious, we asked them to fill the questionnaire again as the post-test measurement. The result can be seen in Table 5 below:

TABLE V. POST-TEST

\begin{tabular}{|l|c|c|c|c|c|c|c|c|c|}
\hline \multirow{2}{*}{ Initial } & \multicolumn{7}{|c|}{ Question } & \multirow{2}{*}{ Total } \\
\cline { 2 - 10 } & $\mathbf{1}$ & $\mathbf{2}$ & $\mathbf{3}$ & $\mathbf{4}$ & $\mathbf{5}$ & $\mathbf{6}$ & $\mathbf{7}$ & $\boldsymbol{8}$ & \\
\hline $\mathrm{L} 1$ & 5 & 5 & 5 & 5 & 5 & 5 & 5 & 5 & 40 \\
\hline $\mathrm{MH}$ & 5 & 5 & 5 & 5 & 5 & 5 & 5 & 5 & 40 \\
\hline $\mathrm{P}$ & 5 & 5 & 5 & 5 & 5 & 5 & 5 & 5 & 40 \\
\hline L2 & 4 & 5 & 5 & 5 & 5 & 4 & 5 & 5 & 38 \\
\hline $\mathrm{Q}$ & 5 & 5 & 4 & 4 & 5 & 5 & 5 & 5 & 38 \\
\hline $\mathrm{AD}$ & 5 & 5 & 5 & 5 & 5 & 5 & 5 & 5 & 40 \\
\hline $\mathrm{A}$ & 5 & 5 & 4 & 5 & 5 & 4 & 5 & 5 & 38 \\
\hline $\mathrm{U}$ & 5 & 5 & 4 & 4 & 4 & 3 & 4 & 4 & 33 \\
\hline ES & 5 & 5 & 4 & 5 & 4 & 5 & 5 & 4 & 37 \\
\hline $\mathrm{AK}$ & 5 & 5 & 5 & 5 & 5 & 5 & 5 & 5 & 40 \\
\hline
\end{tabular}

After getting the result of the post-test, we analyzed the data to find whether the treatment we gave to them brought an effective effect or not. The data from the pre-test and post-test were analyzed by using SPSS. The description of the analysis result including the paired samples statistics, the paired samples correlation and the paired sample test using the TTest formula can be seen in the tables below.

TABLE VI. PAIRED SAMPLES STATISTICS

\begin{tabular}{|l|l|l|l|l|l|}
\hline \multicolumn{2}{|c|}{} & \multicolumn{1}{|c|}{ Mean } & \multicolumn{1}{|c|}{ N } & Std. Deviation & Std. Error Mean \\
\hline \multirow{2}{*}{ Pair 1 } & Pretest & 34.0000 & 10 & 3.39935 & 1.07497 \\
\cline { 2 - 6 } & Posttest & 38.4000 & 10 & 2.22111 & 0.70238 \\
\hline
\end{tabular}

\begin{tabular}{|c|c|c|c|c|c|c|c|c|c|}
\hline & \multicolumn{5}{|c|}{ Paired Differences } & \multirow[t]{3}{*}{$\mathbf{t}$} & \multirow[t]{3}{*}{ df } & \multirow{3}{*}{$\begin{array}{l}\text { Sig. (2- } \\
\text { tailed) }\end{array}$} \\
\hline & & \multirow[t]{2}{*}{ Mean } & \multirow[t]{2}{*}{$\begin{array}{c}\text { Std. } \\
\text { Deviation }\end{array}$} & \multirow[t]{2}{*}{\begin{tabular}{|c|} 
Std. \\
Error \\
Mean
\end{tabular}} & \multicolumn{2}{|c|}{$\begin{array}{l}\text { 95\% Confidence } \\
\text { Interval of the } \\
\text { Difference }\end{array}$} & & & \\
\hline & & & & & Lower & Upper & & & \\
\hline Pair & $\begin{array}{l}\text { Pretest- } \\
\text { Posttest }\end{array}$ & 4.40000 & 1.42984 & 0.45216 & 5.42285 & 3.37715 & 9.731 & 9 & 0.000 \\
\hline
\end{tabular}

TABLE VII. PAIRED SAMPLES CORRELATIONS

\begin{tabular}{|ll|l|l|c|}
\hline & \multicolumn{1}{|c|}{ N } & Correlation & Sig. \\
\hline Pair 1 & Pretest \& Posttest & 10 & 0.957 & 0.000 \\
\hline
\end{tabular}

TABLE VIII. PAIRED SAMPLES TEST 
According to the calculation above, the significance was showing a high level of significance where the score was 0.000 . This means the hypnosis technique was effective to be applied to the affective booster. The result shows that the hypnosis met the psychological condition of the students and was able to touch their feeling. The technique succeeded to awaken the under-conscious world of them and made them able to boost their spirit related to the affective domain.

\section{CONCLUSION}

Teaching and learning process are not separated from the feeling involved in the affective domain owned by a human being. This domain plays a big role in the success of teaching and learning. In order to make this domain works well, the teacher should be able to find and apply the appropriate techniques. In this paper, we have conducted pre-experimental research by applying a technique called hypnosis in order to boost the affective side of the students. The hypnosis stages were synchronized with the level of the students and the textual condition of problems that may affect their affective sides. From the research we conducted, we finally managed to figure out that the hypnosis worked well to help them boosting their good feeling and emotion and eliminating the negative threats coming from the negative affective domains. Simply, the result of the analysis shows that hypnosis was an effective technique.

\section{REFERENCES}

[1] H. D. Brown, Teaching by Principles: An Interactive Approach to Language Pedagogy. New Jersey: Prentice Hall Regents, 1994.

[2] K. Alderson, The Complete Guide to Improving your Grades through Self-Hypnosis. Canada: Insomniac Press, 2004.

[3] D. Barrett, Hypnosis and Hypnotherapy. California: ABC-CLIO, LLC, 2010.

[4] C. I. Hyatt and S. Christopher, Energized Hypnosis: A Non-book for Self Change. Arizona: New Falcon Publications, 2005.

[5] S. S. McMillan and H. James, Research in Education: A Conceptual Introduction. New York: Longman, 2001. 